\title{
The Use of Copper Oxides as Cross-Linking Substances for Chloroprene Rubber and Study of the Vulcanizates Properties. Part I
}

\author{
Piotr Kobędza * (D), Aleksandra Smejda-Krzewicka (D) and Krzysztof Strzelec (D) \\ Faculty of Chemistry, Institute of Polymer and Dye Technology, Lodz University of Technology, \\ Stefanowskiego 16, 90-537 Łódź, Poland; aleksandra.smejda-krzewicka@p.lodz.pl (A.S.-K.); \\ krzysztof.strzelec@p.lodz.pl (K.S.) \\ * Correspondence: piotr.kobedza@dokt.p.lodz.pl
}

Citation: Kobędza, P.;

Smejda-Krzewicka, A.; Strzelec, K.

The Use of Copper Oxides as

Cross-Linking Substances for

Chloroprene Rubber and Study of the

Vulcanizates Properties. Part I.

Materials 2021, 14, 5535. https://

doi.org/10.3390/ma14195535

Academic Editor: Gabriele Milani

Received: 2 August 2021

Accepted: 15 September 2021

Published: 24 September 2021

Publisher's Note: MDPI stays neutral with regard to jurisdictional claims in published maps and institutional affiliations.

Copyright: (c) 2021 by the authors. Licensee MDPI, Basel, Switzerland. This article is an open access article distributed under the terms and conditions of the Creative Commons Attribution (CC BY) license (https:// creativecommons.org/licenses/by/ $4.0 /)$.

\begin{abstract}
The purpose of this work was to verify the ability to cross-link the chloroprene rubber (CR) by using copper oxides: copper(I) oxide or copper(II) oxide. The use of copper oxides arises from the need to limit the application of $\mathrm{ZnO}$ as a cross-linking agent of CR. The obtained results indicate that CR compositions cross-linked with copper oxides are characterized by good mechanical properties and a high cross-linking degree. The results show that the type and the amount of copper oxides influence the cross-linking of the $\mathrm{CR}$ and the properties of the vulcanizates. For compositions containing copper(II) oxide, the properties are linearly dependent on the amount of $\mathrm{CuO}$. Such a relationship is difficult to notice in the case of the use of copper(I) oxide-when analyzing individual parameters, the best results are obtained for different samples. Infrared spectroscopy (IR) studies confirmed the possibility of cross-linking of chloroprene rubber with copper oxides. This is evidenced by the characteristic changes in the intensity of the bands. Structural changes in the material during heating were determined by the thermal analysis-differential scanning calorimetry (DSC) and thermogravimetric analysis (TGA). Regardless of the type and amount of copper oxide, all compositions exhibit similar characteristics, and there are no significant changes in the glass transition temperature of the material.
\end{abstract}

Keywords: chloroprene rubber; copper(I) oxide; copper(II) oxide; cross-linking; IR; DSC; TGA; mechanical properties

\section{Introduction}

Metal oxides are inorganic compounds widely used in polymer processing technology. They can be used as cross-linking agents, activators, and fillers, as well as desiccants or pigments, in amounts usually several phr. Due to their characteristics, metal oxides usually fulfill several functions simultaneously, e.g., a filler and colorant [1-3].

The most important component in the rubber mixture, next to the rubber itself, is the cross-linking substance. Under the influence of the cross-linking substance, a network is formed through the bonds connecting the chains of elastomers. In elastomer technology, metal oxides are used to cross-link materials containing atoms belonging to the halogen group in their main chains. This rubber group includes chloroprene rubber [4-8], chlorosulfonated polyethylene [9] and halogenobutyl rubbers: chlorobutyl [10-12] and bromobutyl [12,13]. For cross-linking of these materials, a mixture of two oxides is used: zinc oxide [4-16] and magnesium oxide [4,6-9,11,13,14,16-18]. Zinc oxide is a compound in the form of white hexagonal crystals. Magnesium oxide is in the form of a white, finely divided powder. Cross-linking of rubber containing halogen atoms occurs as a result of the reaction of this atom with zinc oxide, resulting in the formation of a Lewis acid (e.g., zinc chloride) [5-7,10,15]., whereas magnesium oxide is an acceptor of the formed hydrogen chloride [15]. Additionally, $\mathrm{ZnO}$ and $\mathrm{MgO}$ can be used for the cross-linking of carboxylated acrylonitrile-butadiene rubber [16-18]. 
Substances not commonly used up till now are copper oxides and iron oxides. Copper(I) oxide is in the form of a red-brown powder and occurs in the natural environment as cuprite. Copper(II) oxide is in the form of a black powder. Iron(III) oxide, in the form of a brown powder, commonly occurs as rust, while, in nature, it can be found as hematite. However, iron(II,III) oxide, in the form of a black powder, exists as magnetite. Copper oxides and iron oxides can substitute zinc oxide and magnesium oxide in the cross-linking of chloroprene rubber, chlorosulfonated polyethylene, or chlorobutyl rubber. Copper oxides and iron oxides are also effective in cross-linking CR and chlorosulfonated polyethylene (CSM) mixtures with styrene-butadiene rubber and butadiene rubber [19-27].

Another important function of metal oxides in rubber mixtures is their filling. The main function of the fillers is their influence on the processing properties of the mixtures, as well as providing appropriate mechanical and functional (physical and chemical) properties of rubber products. However, in the technology of elastomers, metal oxides are more often used as a component of another (mineral) filler than separately. Aluminum(III) oxide in its pure form is not used as a filler, but it is an important building block of aluminosilicates used in polymer technology, namely kaolin. Kaolin, a product of natural weathering of igneous rocks, contains kaolinite, i.e., phyllosilicate, as the main ingredient. Kaolin occurs in the form of a white or cream powder. Kaolin is used as a cheap semi-active filler but also causes blistering of the vulcanizate [28-31]. Calcium oxide is also used as a filler [32]. $\mathrm{CaO}$ is a white powder, obtained by burning limestone. $\mathrm{ZnO}$ also exhibits vulcanizate strengthening properties. However, both $\mathrm{CaO}$ and $\mathrm{ZnO}$ are at most semi-reactive fillers and are, therefore, rarely used as the primary filler [32]. More often, the incorporation of metal oxide in another function additionally strengthens the entire material.

Activators are used to increase the effectiveness of the accelerator. There are two main types of activators: divalent metal oxides and fatty acids. Often, both types of activators are used simultaneously, with metal oxides being used in greater amounts. Usually, it is 4-6 parts by weight of oxide with 0.5-1.5 parts. wt. acid. As an activator can be used previously mentioned in other functions $\mathrm{ZnO}, \mathrm{MgO}$, or $\mathrm{CaO}$ [33].

Any metal oxide incorporated into the rubber mixture will give it its color; therefore, they can be classified as coloring substances. The most commonly used metal oxide pigment is titanium(IV) oxide [34,35]. $\mathrm{TiO}_{2}$ forms white crystals in three naturally occurring polymorphs: anatase and rutile, crystallizing in the tetragonal system, and brookite forming crystals in the orthorhombic system. Anatase and rutile are common minerals, while brookite belongs to the group of a very rare minerals. $\mathrm{TiO}_{2}$ has one of the purest shades of white; however, it is an expensive material. A cheaper substitute for $\mathrm{TiO}_{2}$ is $\mathrm{ZnO}$ [36].

The purpose of this work was to verify the ability to cross-link the chloroprene rubber (CR) by using copper oxides: copper(I) oxide or copper(II) oxide. Seeking a substitute for $\mathrm{ZnO}$ as a cross-linking agent results from the restrictions on its use implemented by the European Union. As an alternative to $\mathrm{ZnO}$, different metal oxides can be used as a cross-linking agent. The choice of copper oxides results from the ability to cross-link CR blends with styrene-butadiene rubber (SBR) or butadiene rubber (BR) [21-27]. The advantage of using copper oxides is the smaller amount needed for cross-linking elastomer blends containing CR compared to other cross-linkers. A smaller amount of used materials reduces the cost of making the composition.

\section{Experimental Part}

\subsection{Materials}

In this study, chloroprene rubber (Baypren ${ }^{\circledR} 216 \mathrm{MV}$ from Lanxess GmbH, Cologne, Germany), with a density of $1.23 \mathrm{~g} / \mathrm{cm}^{3}$ and Mooney viscosity (ML $1+4100{ }^{\circ} \mathrm{C}$ ) of $43 \pm 5$, was used. As a cross-linking agent, two copper oxides were used: copper(I) oxide (POCH S.A., Gliwice, Poland) with a density of $6.00 \mathrm{~g} / \mathrm{cm}^{3}$, pureness $>99 \%$, and particle size $\leq 7 \mu \mathrm{m}$; and copper(II) oxide (Sigma-Aldrich Chemie GmbH, Steinheim am Albuch, Germany) with a density $6.32 \mathrm{~g} / \mathrm{cm}^{3}$, pureness $98 \%$, and particle size $<10 \mu \mathrm{m}$. For comparison, a composition containing the standard chloroprene rubber cross-linking 
system was made. For this purpose, zinc oxide (Pharma Cosmetic, Cracow, Poland) with a density of $5.47 \mathrm{~g} / \mathrm{cm}^{3}$ and pureness $>99 \%$, and magnesium oxide (PPH Galfarm Sp. $\mathrm{z}$ o. o., Cracow, Poland) with a density of $3.58 \mathrm{~g} / \mathrm{cm}^{3}$; were used. Stearic acid (Chemical Worldwide Business Sp. z o.o., Słupca, Poland) with a density of $0.85 \mathrm{~g} / \mathrm{cm}^{3}$ was used as a dispersing agent.

\subsection{Research Methods}

The chloroprene rubber composites were prepared using a Krupp-Gruson laboratory two-roll mill (Laborwalzwerk 200x450, Krupp-Gruson, Magdeburg-Buckau, Germany) with a roll diameter of $200 \mathrm{~mm}$ and a length of $450 \mathrm{~mm}$. The temperature of the roll was 20-25 ${ }^{\circ} \mathrm{C}$, while the speed of the front roll was $200 \mathrm{rpm}$, with the roll's friction of 1:1.25. The preparation of one composition lasted $10 \mathrm{~min}$. Then, the material was conditioned for $24 \mathrm{~h}$. At the beginning, rubber was incorporated into two-roll mill to plasticize it. Stearic acid was then added to facilitate the insertion of the oxides. Finally, the metal oxides were incorporated: copper(I) oxide, copper(II) oxide, or a mixture of magnesium oxide and zinc oxide (in the given order).

Vulcametric measurements were determined by the Alpha Technologies MDR 2000 rotorless rheometer (MDR 2000, Alpha Technologies, Hudson, OH, USA), heated to $160{ }^{\circ} \mathrm{C}$. The oscillation frequency was $1.67 \mathrm{~Hz}$. The test was $60 \mathrm{~min}$ and performed according to ASTM D5289 [37]. The torque increment after a given time of heating was calculated from Formula (1):

$$
\Delta M_{x}=M_{x}-M_{\min }
$$

Vulcanization was performed in an electrically heated hydraulic press. Appropriate amounts of the compositions were placed in steel molds, which were placed in a press at a temperature of $160{ }^{\circ} \mathrm{C}$ and a pressure of 200 bar. The vulcanization time was $45 \mathrm{~min}$.

The determination of equilibrium volume swelling was performed. Samples were cut from the prepared vulcanizates in four different shapes. Each of them weighed from 25 to $50 \mathrm{mg}$, with an accuracy of $0.1 \mathrm{mg}$. Then, the samples were placed with solvents: toluene or heptane, in a weighing bottle. Prepared samples were placed in a thermostatic chamber for $72 \mathrm{~h}$ at $25 \pm 1^{\circ} \mathrm{C}$, which, after this time, was bathed with diethyl ether, dried on filter paper, and then weighed again. Then, the samples were dried in a dryer at the temperature of $50{ }^{\circ} \mathrm{C}$ to a constant weight, and they were reweighed. The equilibrium volume swelling was calculated from Formula (2):

$$
Q_{V}=Q_{W} \cdot \frac{d_{\mathrm{v}}}{d_{\mathrm{s}}}
$$

The equilibrium weight swelling was calculated from Formula (3):

$$
Q_{w}=\frac{m_{\mathrm{s}}-m_{\mathrm{d}}}{m_{\mathrm{d}}^{*}} .
$$

The reduced sample weight was calculated from Formula (4):

$$
m_{\mathrm{d}}^{*}=m_{\mathrm{d}}-m_{0} \cdot \frac{m_{\mathrm{m}}}{m_{\mathrm{t}}}
$$

Determination of Mooney-Rivlin elasticity constants was performed. The elasticity constants were calculated based on the Mooney-Rivlin Equation (5) [38,39]:

$$
\frac{P}{2 A_{0} \cdot\left(\lambda-\lambda^{-2}\right)}=C_{1}+C_{2} \cdot \lambda^{-1} .
$$


Extraction of vulcanizates in the boiling acetone vapors in a Soxhlet apparatus for $48 \mathrm{~h}$ was performed. After the given time, the samples were dried to a constant weight in a vacuum oven at $50{ }^{\circ} \mathrm{C}$. Results of the extraction allowed to determine the content of non-rubber substances. The value of real extract was calculated from Formula (6):

$$
E_{\mathrm{R}}=\frac{m_{0}-m}{m_{0}} .
$$

Mechanical properties: stress at elongation 100\%, 200\%,300\%, tensile strength, and elongation at break were tested by the universal testing machine ZwickRoell 1435 (1435, ZwickRoell, Ulm, Germany). The tests were performed according to PN-ISO 37:2007 [40].

Infrared spectra were made using the FTIR-ATR method and recorded using a Thermo Scientific Nicolet 6700 FTIR spectrometer (Nicolet 6700 FT-IR Spectrometer, Thermo Fisher Scientific, Waltham, MA, USA). Samples for infrared tests were prepared from elastomer blends before and after their cross-linking.

Thermal analysis-TGA and DSC — was performed using a Mettler Toledo TGA/DSC 1 device (TGA/DSC 1, Mettler-Toledo, Columbus, OH, USA). TGA analyses were performed using a two-step procedure. First, samples of vulcanizates were heated in the temperature range of $25-600{ }^{\circ} \mathrm{C}$ in an argon atmosphere (flow rate $50 \mathrm{~mL} / \mathrm{min}$ ), with a heating rate of $20^{\circ} \mathrm{C} / \mathrm{min}$ Next, the gas was changed into the air (flow rate $50 \mathrm{~mL} / \mathrm{min}$ ), and the heating was continued up to $900{ }^{\circ} \mathrm{C}$, with the same heating rate. DSC measurements were performed on rubbers blends. Samples were heated from $-100{ }^{\circ} \mathrm{C}$ to $250{ }^{\circ} \mathrm{C}$, with a heating rate of $10^{\circ} \mathrm{C} / \mathrm{min}$. Nitrogen $(80 \mathrm{~mL} / \mathrm{min})$ was used as the protective gas, whereas liquid nitrogen was applied to cool the sample before the measurement.

\section{Results and Discussion}

To investigate the ability of chloroprene rubber cross-linking with copper oxides, compositions containing 1, 2, 3, 4, or 5 weight parts of copper oxide/100 weight parts of CR (phr), were prepared (Table 1$)$. The following oxides were used: $\operatorname{copper}(\mathrm{I})$ oxide $\left(\mathrm{Cu}_{2} \mathrm{O}\right)$ or copper(II) oxide (CuO). For comparative purposes, CR cross-linked with a standard crosslinking system, i.e., a mixture of zinc oxide ( $5 \mathrm{phr}$ of $\mathrm{ZnO}$ ) and magnesium oxide (4 phr of $\mathrm{MgO}$ ), was also prepared. In addition, CR was examined with regards to susceptibility to thermal cross-linking by preparing a composition containing only chloroprene rubber. The purpose of copper oxides use is to obtain vulcanizates with better properties compared to the materials obtained with the use of a standard cross-linking system. In addition, the use of zinc oxide is limited and alternatives should be sought.

Table 1. Tested compositions and their designations.

\begin{tabular}{ccccccc}
\hline $\mathbf{C R}$ & $\mathbf{C u}_{\mathbf{2}} \mathbf{O}$ & $\mathbf{C u O}$ & $\mathbf{Z n O}$ & $\mathbf{M g O}$ & Stearic Acid & Symbol \\
\hline 100 & - & - & - & - & 1 & $\mathrm{CR}$ \\
100 & 1 & - & - & - & 1 & $\mathrm{CR} / \mathrm{Cu}_{2} \mathrm{O}-1$ \\
100 & 2 & - & - & - & 1 & $\mathrm{CR} / \mathrm{Cu}_{2} \mathrm{O}-2$ \\
100 & 3 & - & - & - & 1 & $\mathrm{CR} / \mathrm{Cu}_{2} \mathrm{O}-3$ \\
100 & 4 & - & - & - & 1 & $\mathrm{CR} / \mathrm{Cu}_{2} \mathrm{O}-4$ \\
100 & 5 & - & - & - & 1 & $\mathrm{CR} / \mathrm{Cu}_{2} \mathrm{O}-5$ \\
100 & - & 1 & - & - & 1 & $\mathrm{CR} / \mathrm{CuO}-1$ \\
100 & - & 2 & - & - & 1 & $\mathrm{CR} / \mathrm{CuO}-2$ \\
100 & - & 3 & - & - & 1 & $\mathrm{CR} / \mathrm{CuO}-3$ \\
100 & - & 4 & - & - & 1 & $\mathrm{CR} / \mathrm{CuO}-4$ \\
100 & - & 5 & - & - & 1 & $\mathrm{CR} / \mathrm{CuO}-5$ \\
100 & - & - & 5 & 4 & 1 & $\mathrm{CR} / \mathrm{ZnO} / \mathrm{MgO}$ \\
\hline
\end{tabular}




\subsection{Vulcametric Parameters of $C R$ Compositions Containing Copper Oxides}

To determine the possibility of cross-linking chloroprene rubber with copper oxides and the characteristics of the vulcanization course, vulcametric parameters were determined. The results showed that the compositions containing copper(I) oxide were characterized by scorch time in the range from 2.7 (for the $\mathrm{CR} / \mathrm{Cu}_{2} \mathrm{O}-2$ ) to $7.4 \mathrm{~min}$ (for the $\mathrm{CR} / \mathrm{Cu}_{2} \mathrm{O}-5$ ) (Table 2, Figure 1). For compositions containing copper(II) oxide, the $t_{02}$ values were from 1.7 (for the $\mathrm{CR} / \mathrm{CuO}-4$ ) to $8.1 \mathrm{~min}$ (for the $\mathrm{CR} / \mathrm{CuO}-1$ ) (Table 2, Figure 2). For comparison, the scorch time of the CR compound containing the conventional crosslinking system was equal to $4.5 \mathrm{~min}$. However, for CR without any metal oxide, $t_{02}$ was $6.4 \mathrm{~min}$.

The shortest vulcanization time was obtained for the $\mathrm{CR} / \mathrm{ZnO} / \mathrm{MgO}$, equal to $27.5 \mathrm{~min}$. Replacing zinc oxide and magnesium oxide with copper oxides results in a longer vulcanization time. For the $\mathrm{CR} / \mathrm{Cu}_{2} \mathrm{O}-1, t_{90}=38.8 \mathrm{~min}$. As the content of $\mathrm{Cu}_{2} \mathrm{O}$ in the compound increases, the vulcanization time lengthens, reaching $53.7 \mathrm{~min}$ for the $\mathrm{CR} / \mathrm{Cu}_{2} \mathrm{O}-5$. In the case of compositions containing $\mathrm{CuO}$, the shortest vulcanization time was obtained for the $\mathrm{CR} / \mathrm{CuO}-4\left(t_{90}=38.6 \mathrm{~min}\right)$, while the longest vulcanization time was achieved for the $\mathrm{CR} / \mathrm{CuO}-3\left(t_{90}=44.9 \mathrm{~min}\right)$. For the $\mathrm{CR}$ without any metal oxide, $t_{90}=49.0 \mathrm{~min}$.

The minimum torque for the compounds containing $3-5 \mathrm{phr}$ of $\mathrm{Cu}_{2} \mathrm{O}$ and $5 \mathrm{phr}$ of $\mathrm{CuO}$ was equal to $0.59 \mathrm{dN} \cdot \mathrm{m}$. The same value was obtained for the composition containing zinc oxide and magnesium oxide. For the $\mathrm{CR} / \mathrm{Cu}_{2} \mathrm{O}-1$, the minimum torque was the smallest and equal to $0.53 \mathrm{dN} \cdot \mathrm{m}$, whereas the minimum torque was the greatest for the $\mathrm{CR} / \mathrm{CuO}-4$ $\left(M_{\min }=0.62 \mathrm{dN} \cdot \mathrm{m}\right)$. For $\mathrm{CR}$ without metal oxide, $M_{\min }=0.55 \mathrm{dN} \cdot \mathrm{m}$. These results indicate that all prepared blends had similar viscosity.

Torque increment after $45 \mathrm{~min}$ of heating of the $\mathrm{CR} / \mathrm{Cu}_{2} \mathrm{O}-5$ was the largest and equal to $3.91 \mathrm{dN} \cdot \mathrm{m}$. With the decreasing amount of $\mathrm{Cu}_{2} \mathrm{O}$ in the compounds, the value of the torque increment also decreased, reaching the value of $2.63 \mathrm{dN} \cdot \mathrm{m}$ for the $\mathrm{CR} / \mathrm{Cu}_{2} \mathrm{O}-1$. For the compositions containing copper(II) oxide, the greatest value of torque increment after $45 \mathrm{~min}$ of heating was obtained for the CR/CuO-5 $\left(\Delta M_{45}=2.65 \mathrm{dN} \cdot \mathrm{m}\right)$. For the application of the copper(II) oxide, with the decreasing amount of $\mathrm{CuO}$ in the composition, the torque increment also decreases, as in the case of $\mathrm{Cu}_{2} \mathrm{O}$. For the $\mathrm{CR} / \mathrm{CuO}-1, \Delta \mathrm{M}_{45}=0.88 \mathrm{dN} \cdot \mathrm{m}$. The CR without any metal oxide obtained the value of $\Delta M_{45}=1.86 \mathrm{dN} \cdot \mathrm{m}$, while, for the $\mathrm{CR}$ containing the standard cross-linking system, $\Delta M_{45}=3.77 \mathrm{dN} \cdot \mathrm{m}$.

The obtained results show that, with an increasing amount of copper oxides in the chloroprene rubber, the torque increment also increases. Compounds containing copper(I) oxide achieve higher values of the torque increment than compositions containing copper(II) oxide. For the $\mathrm{CR} / \mathrm{Cu}_{2} \mathrm{O}-1, \mathrm{CR} / \mathrm{CuO}-4$, and $\mathrm{CR} / \mathrm{CuO}-5$, the values of the torque increment were averagely $2.64 \mathrm{dN} \cdot \mathrm{m}$. This indicates that copper(I) oxide is more effective in creating bonds between the chains of chloroprene rubber-the minimum amount of $\mathrm{Cu}_{2} \mathrm{O}$ is as effective in cross-linking as larger amounts of copper(II) oxide (4-5 phr of $\mathrm{CuO}$ ). This may indicate the formation of a more complex network structure in the case of using $\mathrm{Cu}_{2} \mathrm{O}$. The torque after heating the $\mathrm{CR} / \mathrm{Cu}_{2} \mathrm{O}-5$ for $45 \mathrm{~min}$ is greater than for the $\mathrm{CR} / \mathrm{ZnO} / \mathrm{MgO}$. The scorch time of the compositions containing 1-3 phr of $\mathrm{Cu}_{2} \mathrm{O}$ or at least $2 \mathrm{phr}$ of $\mathrm{CuO}$ is shorter than for the $\mathrm{CR} / \mathrm{ZnO} / \mathrm{MgO}$. The incorporation of copper oxide, regardless of its type or amount, causes a longer vulcanization time than in the case of zinc oxide and magnesium oxide. Such results indicate a faster start of cross-linking of the composition, simultaneously extending the entire process. This may arise from the need to supply more energy needed to efficiently use all the incorporated copper oxide. 
Table 2. Vulcametric parameters of the tested compositions determined at the temperature $160^{\circ} \mathrm{C}$.

\begin{tabular}{ccccc}
\hline Symbol & $\boldsymbol{t}_{\mathbf{0 2}}(\mathbf{m i n})$ & $\boldsymbol{t}_{\mathbf{9 0}}(\mathbf{m i n})$ & $\boldsymbol{M}_{\boldsymbol{m i n}}(\mathbf{d N} \cdot \mathbf{m})$ & $\boldsymbol{\Delta}_{\mathbf{M}_{\mathbf{4 5}}}(\mathbf{d N} \cdot \mathbf{m})$ \\
\hline $\mathrm{CR}$ & 6.4 & 49.0 & 0.55 & 1.86 \\
$\mathrm{CR} / \mathrm{Cu}_{2} \mathrm{O}-1$ & 3.3 & 38.8 & 0.53 & 2.63 \\
$\mathrm{CR} / \mathrm{Cu}_{2} \mathrm{O}-2$ & 2.7 & 48.7 & 0.56 & 2.69 \\
$\mathrm{CR} / \mathrm{Cu}_{2} \mathrm{O}-3$ & 3.1 & 51.0 & 0.59 & 2.78 \\
$\mathrm{CR} / \mathrm{Cu}_{2} \mathrm{O}-4$ & 4.7 & 52.9 & 0.59 & 2.98 \\
$\mathrm{CR} / \mathrm{Cu}_{2} \mathrm{O}-5$ & 7.4 & 53.7 & 0.59 & 3.91 \\
$\mathrm{CR} / \mathrm{CuO}-1$ & 8.1 & 44.1 & 0.58 & 0.88 \\
$\mathrm{CR} / \mathrm{CuO}-2$ & 3.4 & 42.3 & 0.58 & 1.19 \\
$\mathrm{CR} / \mathrm{CuO}-3$ & 3.1 & 44.9 & 0.61 & 2.10 \\
$\mathrm{CR} / \mathrm{CuO}-4$ & 1.7 & 38.6 & 0.62 & 2.64 \\
$\mathrm{CR} / \mathrm{CuO}-5$ & 2.0 & 38.8 & 0.59 & 2.65 \\
$\mathrm{CR} / \mathrm{ZnO} / \mathrm{MgO}$ & 4.5 & 27.5 & 0.59 & 3.77 \\
\hline
\end{tabular}

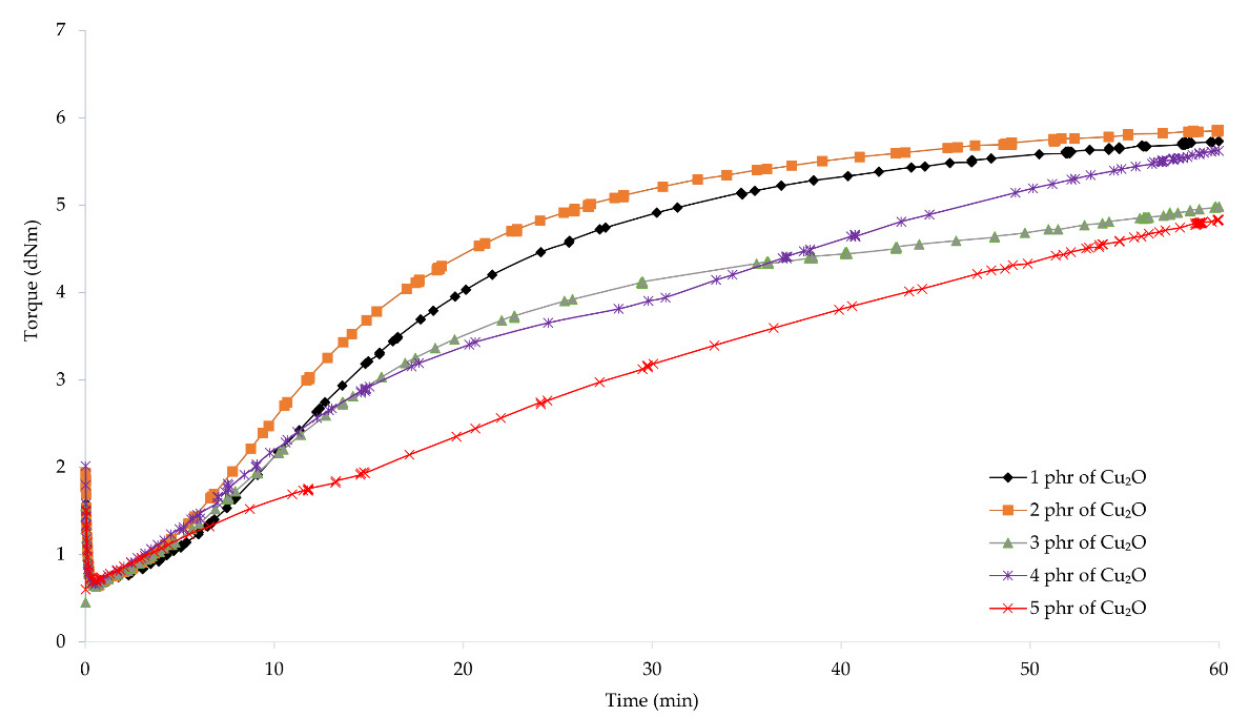

Figure 1. Vulcametric kinetics of chloroprene rubber cross-linked with copper(I) oxide (1-5 phr of $\left.\mathrm{Cu}_{2} \mathrm{O}\right)$.

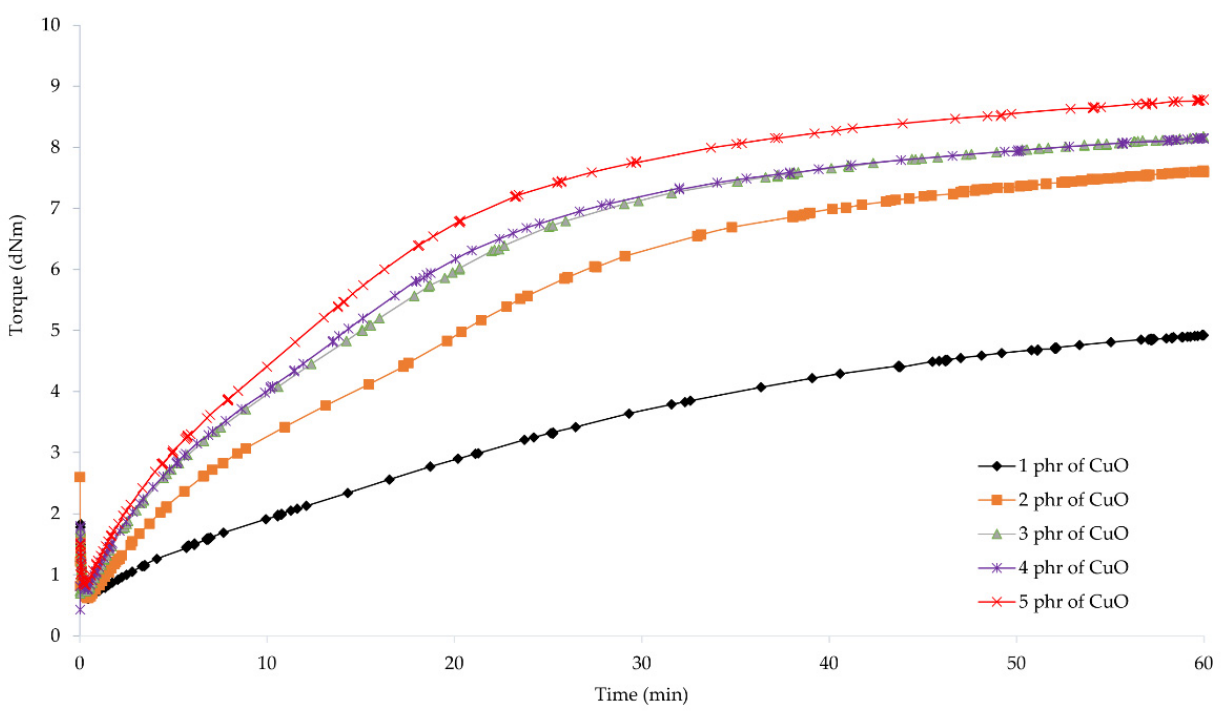

Figure 2. Vulcametric kinetics of chloroprene rubber cross-linked with copper(II) oxide (1-5 phr of CuO). 


\subsection{Equilibrium Volume Swelling of CR Cross-Linked with Copper Oxides}

Obtained results of equilibrium volume swelling confirmed the conclusions of the analysis of the vulcametric kinetics that the presence of copper oxide causes cross-linking of chloroprene rubber. The highest value of equilibrium volume swelling in toluene $\left(Q_{V}{ }^{\mathrm{T}}=19.26 \mathrm{~cm}^{3} / \mathrm{cm}^{3}\right)$ was obtained for thermo-cross-linked vulcanizates (Table 3). CR cross-linked with $\mathrm{CuO}$ achieved lower $Q_{V}{ }^{\mathrm{T}}$ values than $\mathrm{CR}$ cross-linked with $\mathrm{Cu}_{2} \mathrm{O}$. The lowest value of equilibrium volume swelling in toluene $\left(Q_{V}^{T}=4.68 \mathrm{~cm}^{3} / \mathrm{cm}^{3}\right)$ was achieved for the $\mathrm{CR} / \mathrm{CuO}-5$. Very similar results were obtained for vulcanizates containing 3 and $4 \mathrm{phr}$ of $\mathrm{CuO}$. In the case of the use of $\mathrm{CuO}$ as the cross-linking agent, the highest value was obtained for the CR/CuO-1, for which $Q_{V}^{T}=8.39 \mathrm{~cm}^{3} / \mathrm{cm}^{3}$. This value is still lower than the lowest value of the equilibrium volume swelling in toluene for vulcanizates containing copper(I) oxide $\left(Q_{V}{ }^{\mathrm{T}}=8.50 \mathrm{~cm}^{3} / \mathrm{cm}^{3}\right.$ for the $\left.\mathrm{CR} / \mathrm{Cu}_{2} \mathrm{O}-1\right)$. In turn, the highest $Q_{V}{ }^{\mathrm{T}}$ value, equal to $10.56 \mathrm{~cm}^{3} / \mathrm{cm}^{3}$, was achieved for the $\mathrm{CR} / \mathrm{Cu}_{2} \mathrm{O}-2$. For comparison, the $Q_{V}{ }^{\mathrm{T}}$ value for the $\mathrm{CR} / \mathrm{ZnO} / \mathrm{MgO}$ was equal to $12.24 \mathrm{~cm}^{3} / \mathrm{cm}^{3}$.

In the case of equilibrium volume swelling in heptane, the values are comparable for all vulcanizates containing copper oxide. For vulcanizates containing copper(I) oxide, the $Q_{V}{ }^{\mathrm{H}}$ values ranged from $0.37 \mathrm{~cm}^{3} / \mathrm{cm}^{3}$ (for the $\mathrm{CR} / \mathrm{Cu}_{2} \mathrm{O}-4$ ) to $0.51 \mathrm{~cm}^{3} / \mathrm{cm}^{3}$ (for the $\mathrm{CR} / \mathrm{Cu}_{2} \mathrm{O}-1$ ). For vulcanizates containing copper(II) oxide, the lowest equilibrium volume swelling in heptane was obtained for the CR/CuO-1 $\left(Q_{V}{ }^{\mathrm{H}}=0.38 \mathrm{~cm}^{3} / \mathrm{cm}^{3}\right)$, while the highest value was achieved for the CR/CuO-5 $\left(Q_{V}{ }^{\mathrm{H}}=0.48 \mathrm{~cm}^{3} / \mathrm{cm}^{3}\right)$. For comparison, $Q_{V}{ }^{\mathrm{H}}=0.39 \mathrm{~cm}^{3} / \mathrm{cm}^{3}$ for thermo-cross-linked CR, while, for vulcanizate containing $\mathrm{ZnO}$ and $\mathrm{MgO}, Q_{V}{ }^{\mathrm{H}}=0.45 \mathrm{~cm}^{3} / \mathrm{cm}^{3}$.

The results of the equilibrium swelling measurements show that $\mathrm{CR}$ cross-linked with copper(II) oxide exhibits greater resistance to solvents. This proves a good crosslinking degree of these vulcanizates. It can also be observed that, with the increasing amount of $\mathrm{CuO}$ in the vulcanizate, the $Q_{V}^{\mathrm{T}}$ value decreases; thus, the cross-linking degree increases, reaching almost identical values for the content of $3-5 \mathrm{phr}$ of $\mathrm{CuO}$. This proves the formation of an increasingly complex network structure along with the increasing amount of $\mathrm{CuO}$ in the composition. Moreover, the use of larger amounts of copper(II) oxide does not proportionally affect the expansion of the network. A similar relationship is not maintained for $\mathrm{CR}$ cross-linked with $\mathrm{Cu}_{2} \mathrm{O}$. The lowest $Q_{V}{ }^{\mathrm{T}}$ value was obtained for the $\mathrm{CR} / \mathrm{Cu}_{2} \mathrm{O}-1$, and the highest for the $\mathrm{CR} / \mathrm{Cu}_{2} \mathrm{O}-2$. However, as the content of copper(I) oxide exceeds $2 \mathrm{phr}$, the $Q_{V}{ }^{\mathrm{T}}$ value decreases, reaching $9.76 \mathrm{~cm}^{3} / \mathrm{cm}^{3}$ for the $\mathrm{CR} / \mathrm{Cu}_{2} \mathrm{O}-5$. Such results may indicate the agglomeration of $\mathrm{Cu}_{2} \mathrm{O}$ and, consequently, a reduction in the cross-linking efficiency of the composition. Importantly, the use of copper oxides results in a $Q_{V}{ }^{\mathrm{T}}$ value lower than in the case of conventionally cross-linked $\mathrm{CR}$ (with $\mathrm{ZnO}$ and $\mathrm{MgO}$ ), which proves the effectiveness of $\mathrm{Cu}_{2} \mathrm{O}$ and $\mathrm{CuO}$ as the cross-linking agent, forming a complex network structure.

Table 3. Values of equilibrium swelling, elasticity constants, and real extract of CR vulcanizates; $\mathrm{T}=160{ }^{\circ} \mathrm{C}, t=45 \mathrm{~min}$.

\begin{tabular}{|c|c|c|c|c|c|}
\hline Symbol & $Q_{V}^{\mathrm{T}}\left(\mathrm{cm}^{3} / \mathrm{cm}^{3}\right)$ & $Q_{V}^{\mathrm{H}}\left(\mathrm{cm}^{3} / \mathrm{cm}^{3}\right)$ & $C_{1}\left(\mathrm{kG} / \mathrm{cm}^{2}\right)$ & $C_{2}\left(\mathrm{kG} / \mathrm{cm}^{2}\right)$ & $E_{\mathrm{R}}(\mathrm{mg} / \mathrm{mg})$ \\
\hline CR & $19.26 \pm 0.35$ & $0.39 \pm 0.03$ & 0.34 & 2.22 & 0.090 \\
\hline $\mathrm{CR} / \mathrm{Cu}_{2} \mathrm{O}-1$ & $8.50 \pm 0.09$ & $0.51 \pm 0.10$ & 0.47 & 0.50 & 0.093 \\
\hline $\mathrm{CR} / \mathrm{Cu}_{2} \mathrm{O}-2$ & $10.56 \pm 0.45$ & $0.38 \pm 0.01$ & 0.64 & 1.09 & 0.102 \\
\hline $\mathrm{CR} / \mathrm{Cu}_{2} \mathrm{O}-3$ & $10.38 \pm 0.39$ & $0.40 \pm 0.07$ & 0.67 & 1.15 & 0.084 \\
\hline $\mathrm{CR} / \mathrm{Cu}_{2} \mathrm{O}-4$ & $10.22 \pm 0.43$ & $0.37 \pm 0.02$ & 0.55 & 1,88 & 0.097 \\
\hline $\mathrm{CR} / \mathrm{Cu}_{2} \mathrm{O}-5$ & $9.76 \pm 0.13$ & $0.40 \pm 0.02$ & 0.62 & 2.44 & 0.084 \\
\hline $\mathrm{CR} / \mathrm{CuO}-1$ & $8.39 \pm 0.22$ & $0.38 \pm 0.02$ & 0.38 & 2.53 & 0.090 \\
\hline $\mathrm{CR} / \mathrm{CuO}-2$ & $7.48 \pm 0.40$ & $0.42 \pm 0.04$ & 0.66 & 3.70 & 0.084 \\
\hline $\mathrm{CR} / \mathrm{CuO}-3$ & $4.70 \pm 0.18$ & $0.45 \pm 0.03$ & 0.71 & 2.37 & 0.066 \\
\hline $\mathrm{CR} / \mathrm{CuO}-4$ & $4.69 \pm 0.09$ & $0.45 \pm 0.04$ & 1.04 & 1.62 & 0.058 \\
\hline $\mathrm{CR} / \mathrm{CuO}-5$ & $4.68 \pm 0.06$ & $0.48 \pm 0.02$ & 1.32 & 1.36 & 0.057 \\
\hline $\mathrm{CR} / \mathrm{ZnO} / \mathrm{MgO}$ & $12.24 \pm 0.64$ & $0.45 \pm 0.01$ & 0.58 & 0.46 & 0.159 \\
\hline
\end{tabular}




\subsection{Analysis of the Cross-Linking Degree by Determining the Elasticity Constants}

The elasticity constants calculated from the Mooney-Rivlin equation allow the determination of the network formed during the cross-linking. The first elasticity constant is related to the cross-linking degree - the greater the constant value, the greater the vulcanizate cross-linking degree is. The second elasticity constant can be equated with the deviation of the obtained network from the ideal network. For vulcanizates containing $\mathrm{Cu}_{2} \mathrm{O}$, the lowest value of $C_{1}$ was equal to $0.47 \mathrm{kG} / \mathrm{cm}^{2}$ (for the $\mathrm{CR} / \mathrm{Cu}_{2} \mathrm{O}-1$ ), while the highest value was equal to $0.67 \mathrm{kG} / \mathrm{cm}^{2}$ (for the $\mathrm{CR} / \mathrm{Cu}_{2} \mathrm{O}-3$ ) (Table 3). The value of the second elasticity constant was also the lowest for the $\mathrm{CR} / \mathrm{Cu}_{2} \mathrm{O}-1\left(C_{2}=0.50 \mathrm{kG} / \mathrm{cm}^{2}\right)$, while the highest for the $\mathrm{CR} / \mathrm{Cu}_{2} \mathrm{O}-5\left(C_{2}=2.44 \mathrm{kG} / \mathrm{cm}^{2}\right)$. For vulcanizates containing $\mathrm{CuO}$, the lowest value of $C_{1}$ was equal to $0.38 \mathrm{kG} / \mathrm{cm}^{2}$ (for the $\mathrm{CR} / \mathrm{CuO}-1$ ), while the highest was equal to $1.32 \mathrm{kG} / \mathrm{cm}^{2}$ (for the $\mathrm{CR} / \mathrm{CuO}-5$ ). In the case of $C_{2}$, the lowest value was recorded for the $\mathrm{CR} / \mathrm{CuO}-5\left(C_{2}=1.36 \mathrm{kG} / \mathrm{cm}^{2}\right)$, and the highest for the $\mathrm{CR} / \mathrm{CuO}-2$ $\left(C_{2}=3.70 \mathrm{kG} / \mathrm{cm}^{2}\right)$. For comparison, the thermo-cross-linked $C R$ vulcanizate obtained the lowest value of the first elasticity constant among all the tested samples $\left(C_{1}=0.34 \mathrm{kG} / \mathrm{cm}^{2}\right)$. The value of $C_{2}$ was equal to $2.22 \mathrm{kG} / \mathrm{cm}^{2}$. In turn, the vulcanizate containing $\mathrm{ZnO}$ and $\mathrm{MgO}$ was characterized by the value of $C_{1}$ equal to $0.58 \mathrm{kG} / \mathrm{cm}^{2}$. This is a lower value of the $C_{1}$ constant than for the vulcanizates containing at least $2 \mathrm{phr}$ of $\mathrm{CuO}$ or $\mathrm{Cu}_{2} \mathrm{O}$ (except for the $\mathrm{CR} / \mathrm{Cu}_{2} \mathrm{O}-4$, for which $C_{1}=0.55 \mathrm{kG} / \mathrm{cm}^{2}$ ). The value of the $C_{2}$ constant was the smallest among all tested samples $\left(C_{2}=0.46 \mathrm{kG} / \mathrm{cm}^{2}\right)$.

The analysis of the elasticity constants results confirms the possibility of $\mathrm{CR}$ crosslinking with copper oxides. Higher values of the first elasticity constant, equated to an increase in the cross-linking degree, were obtained for vulcanizates containing $\mathrm{CuO}$. The use of $2 \mathrm{phr}$ of $\mathrm{CuO}$ results in a value of $C_{1}$ comparable to the use of 2-3 phr of $\mathrm{Cu}_{2} \mathrm{O}$. However, the incorporation of different amounts of $\mathrm{CuO}$ results in a linear relationship-as the amount of $\mathrm{CuO}$ increases, the value of $C_{1}$ also increases. Such a relationship does not occur while applicating $\mathrm{Cu}_{2} \mathrm{O}$. In this case, the $\mathrm{CR} / \mathrm{Cu}_{2} \mathrm{O}-1$ has the lowest value of $C_{1}$, and the $\mathrm{CR} / \mathrm{Cu}_{2} \mathrm{O}-3$ has the highest value. It is noteworthy that the first elasticity constant for conventionally cross-linked CR was lower than for most vulcanizates containing copper oxides. The exceptions were samples containing $1 \mathrm{phr}$ of $\mathrm{Cu}_{2} \mathrm{O}$ or $\mathrm{CuO}$ and $4 \mathrm{phr}$ of $\mathrm{Cu}_{2} \mathrm{O}$. These results confirm the observations from the measurements of the equilibrium volume swelling. The emerging network structure is more complex when more $\mathrm{CuO}$ is incorporated, whereas, when $\mathrm{Cu}_{2} \mathrm{O}$ is used, agglomeration may occur, which hinders the effective use of the oxide.

\subsection{Real Extract of CR Cross-Linked with Copper Oxides}

To confirm that cross-linking of chloroprene rubber with copper oxides leads to the network formation, the cross-linked samples were subjected to exhaustive extraction in the vapor of boiling acetone, which elutes non-rubber components and the gel fraction of $\mathrm{CR}$. The real extract reaches lower values for the samples cross-linked to a greater degree. In the case of $\mathrm{CR}$ cross-linked with $\mathrm{Cu}_{2} \mathrm{O}$, the real extract values ranged from $0.084 \mathrm{mg} / \mathrm{mg}$ (for the $\mathrm{CR} / \mathrm{Cu}_{2} \mathrm{O}-3$ and $\mathrm{CR} / \mathrm{Cu}_{2} \mathrm{O}-5$ ) to $0.102 \mathrm{mg} / \mathrm{mg}$ (for the $\mathrm{CR} / \mathrm{Cu}_{2} \mathrm{O}$ 2) (Table 3). In the case of vulcanizates containing $\mathrm{CuO}$, the value of the real extract decreased with increasing content of copper(II) oxide, reaching the highest value for the $\mathrm{CR} / \mathrm{CuO}-1\left(E_{\mathrm{R}}=0.090 \mathrm{mg} / \mathrm{mg}\right)$, and the lowest for the CR/CuO-5 $\left(E_{\mathrm{R}}=0.057 \mathrm{mg} / \mathrm{mg}\right)$. For comparison, the thermo-cross-linked $C R$ reached $E_{R}=0.090 \mathrm{mg} / \mathrm{mg}$. However, for the $\mathrm{CR} / \mathrm{ZnO} / \mathrm{MgO}, E_{\mathrm{R}}=0.159 \mathrm{mg} / \mathrm{mg}$, which was the highest value among all tested samples.

The analysis of the real extract results shows that the amount and type of copper oxide affect the cross-linking of chloroprene rubber. The use of $\mathrm{CuO}$ as a cross-linking substance is more effective than $\mathrm{Cu}_{2} \mathrm{O}$. As the $\mathrm{CuO}$ content in the vulcanizate increases, the $E_{\mathrm{R}}$ value decreases. When $\mathrm{Cu}_{2} \mathrm{O}$ was used, the highest $E_{R}$ value was obtained for the $\mathrm{CR} / \mathrm{Cu}_{2} \mathrm{O}-2$, and the lowest value was achieved for the samples containing 3 and $5 \mathrm{phr}$ of $\mathrm{Cu}_{2} \mathrm{O}$. The real extract results confirm the hypothesis of $\mathrm{Cu}_{2} \mathrm{O}$ agglomeration, which hinders cross-linking of $\mathrm{CR}$, and the emerging network proportionally complexed to the amount of $\mathrm{CuO}$ used. 
It is important that the real extract values for vulcanizates containing copper oxides are noticeably lower than for the conventionally cross-linked CR sample (with $\mathrm{ZnO}$ and $\mathrm{MgO}$ ).

\subsection{Mechanical Properties of CR Cross-Linked with Copper Oxides}

The performed tests showed that the amount and type of copper oxide affect the mechanical properties of CR vulcanizates. The thermo-cross-linked CR sample obtained the tensile strength value equal to $1.9 \mathrm{MPa}$, which was the lowest value among all tested samples. For the $\mathrm{CR} / \mathrm{Cu}_{2} \mathrm{O}-1, \mathrm{TS}_{\mathrm{b}}=6.9 \mathrm{MPa}$ (Table 4, Figure 3), whereas the incorporation of at least $2 \mathrm{phr}$ of $\mathrm{Cu}_{2} \mathrm{O}$ results in increasing the vulcanizates tensile strength to values in the range from $T S_{b}=10.1 \mathrm{MPa}$ for the $\mathrm{CR} / \mathrm{Cu}_{2} \mathrm{O}-5$, to $T S_{\mathrm{b}}=13.7 \mathrm{MPa}$ for the $\mathrm{CR} / \mathrm{Cu}_{2} \mathrm{O}-4$. A similar dependence can be observed for vulcanizates containing $\mathrm{CuO}$. The incorporation of 1 or $2 \mathrm{phr}$ of $\mathrm{CuO}$ causes a tensile strength value of less than $7 \mathrm{MPa}$ (Table 4, Figure 4), whereas, incorporation of at least $3 \mathrm{phr}$ of $\mathrm{CuO}$ leads to increasing the $T S_{\mathrm{b}}$ to at least $12.1 \mathrm{MPa}$ (for the $\mathrm{CR} / \mathrm{CuO}-4$ ), up to $14.3 \mathrm{MPa}$ (for the $\mathrm{CR} / \mathrm{CuO}-5$ ). For comparison, $\mathrm{CR}$ cross-linked with $\mathrm{ZnO}$ and $\mathrm{MgO}$ was characterized by $T S_{\mathrm{b}}=7.8 \mathrm{MPa}$, which is slightly higher than the tensile strength values of vulcanizates containing small amounts of copper oxides.

The elongation at break of the thermo-cross-linked CR, standard cross-linked (with $\mathrm{ZnO}$ and $\mathrm{MgO}$ ) or cross-linked with copper(I) oxide, was comparable. The thermo-crosslinked CR reached the value of $E_{\mathrm{b}}=779 \%$, while the CR cross-linked with $\mathrm{ZnO}$ and $\mathrm{MgO}$ obtained the value of $E_{\mathrm{b}}=680 \%$. However, the elongation at break values for the CR cross-linked with copper(I) oxide ranged from 614\% (for the $\mathrm{CR} / \mathrm{Cu}_{2} \mathrm{O}-1$ ) to $752 \%$ (for the $\left.\mathrm{CR} / \mathrm{Cu}_{2} \mathrm{O}-3\right)$. In turn, the values of elongation at break for vulcanizates containing $\mathrm{CuO}$ are noticeably higher. They ranged from $822 \%$ (for the $\mathrm{CR} / \mathrm{CuO}-2$ ) to $1092 \%$ (for the $\mathrm{CR} / \mathrm{CuO}-1)$.

The amount and type of copper oxide affect the mechanical properties of the prepared vulcanizates. The use of at least $2 \mathrm{phr}$ of $\mathrm{Cu}_{2} \mathrm{O}$ or $3 \mathrm{phr}$ of $\mathrm{CuO}$ results in obtaining vulcanizates with the tensile strength above $10 \mathrm{MPa}$, while the vulcanizate containing the standard cross-linking system was characterized by the tensile strength of $8 \mathrm{MPa}$. These results indicate that the mechanical strength does not unequivocally correlate with the degree of cross-linking of the composition. This may indicate the additional function of the copper oxides to strengthen the composition. Analysis of the elongation at break result showed that the values for the sample containing $\mathrm{ZnO}$ and $\mathrm{MgO}$ and the samples containing $\mathrm{Cu}_{2} \mathrm{O}$ were comparable, whereas, for vulcanizates containing $\mathrm{CuO}$, the elongation increased from $20 \%$ to even $55 \%$ compared to the reference sample.

Table 4. Mechanical properties of CR vulcanizates; $T=160{ }^{\circ} \mathrm{C}, t=45 \mathrm{~min}$.

\begin{tabular}{cccccc}
\hline Symbol & $S_{\mathbf{e} 100}(\mathbf{M P a})$ & $\left.S_{\mathbf{e} 200} \mathbf{( M P a}\right)$ & $S_{\mathbf{e} 300}(\mathbf{M P a})$ & $\left.\mathbf{T S}_{\mathbf{b}} \mathbf{( M P a}\right)$ & $\boldsymbol{E}_{\mathbf{b}} \mathbf{( \% )}$ \\
\hline $\mathrm{CR}$ & $0.47 \pm 0.01$ & $0.52 \pm 0.01$ & $0.57 \pm 0.02$ & $1.9 \pm 0.2$ & $779 \pm 15$ \\
$\mathrm{CR} / \mathrm{Cu}_{2} \mathrm{O}-1$ & $0.76 \pm 0.06$ & $0.97 \pm 0.10$ & $1.16 \pm 0.14$ & $6.9 \pm 1.2$ & $614 \pm 21$ \\
$\mathrm{CR} / \mathrm{Cu}_{2} \mathrm{O}-2$ & $2.06 \pm 0.10$ & $2.44 \pm 0.17$ & $3.21 \pm 0.27$ & $12.4 \pm 0.9$ & $639 \pm 14$ \\
$\mathrm{CR} / \mathrm{Cu}_{2} \mathrm{O}-3$ & $1.50 \pm 0.19$ & $1.73 \pm 0.19$ & $2.24 \pm 0.21$ & $13.5 \pm 0.5$ & $752 \pm 40$ \\
$\mathrm{CR} / \mathrm{Cu}_{2} \mathrm{O}-4$ & $1.58 \pm 0.06$ & $1.83 \pm 0.08$ & $2.31 \pm 0.10$ & $13.7 \pm 0.7$ & $709 \pm 12$ \\
$\mathrm{CR} / \mathrm{Cu}_{2} \mathrm{O}-5$ & $1.08 \pm 0.02$ & $1.28 \pm 0.01$ & $1.55 \pm 0.01$ & $10.1 \pm 0.5$ & $679 \pm 23$ \\
$\mathrm{CR} / \mathrm{CuO}-1$ & $0.48 \pm 0.01$ & $0.63 \pm 0.02$ & $0.76 \pm 0.04$ & $6.9 \pm 0.7$ & $1092 \pm 41$ \\
$\mathrm{CR} / \mathrm{CuO}-2$ & $0.67 \pm 0.07$ & $1.04 \pm 0.14$ & $1.46 \pm 0.24$ & $6.7 \pm 2.2$ & $822 \pm 130$ \\
$\mathrm{CR} / \mathrm{CuO}-3$ & $0.69 \pm 0.02$ & $0.99 \pm 0.01$ & $1.27 \pm 0.06$ & $13.0 \pm 1.6$ & $962 \pm 100$ \\
$\mathrm{CR} / \mathrm{CuO}-4$ & $0.74 \pm 0.08$ & $1.12 \pm 0.16$ & $1.53 \pm 0.30$ & $12.1 \pm 1.1$ & $917 \pm 85$ \\
$\mathrm{CR} / \mathrm{CuO}-5$ & $0.72 \pm 0.03$ & $0.99 \pm 0.04$ & $1.20 \pm 0.04$ & $14.3 \pm 1.0$ & $1055 \pm 9$ \\
$\mathrm{CR} / \mathrm{ZnO} / \mathrm{MgO}$ & $0.95 \pm 0.17$ & $1.13 \pm 0.19$ & $1.33 \pm 0.21$ & $7.8 \pm 1.2$ & $680 \pm 25$ \\
\hline
\end{tabular}




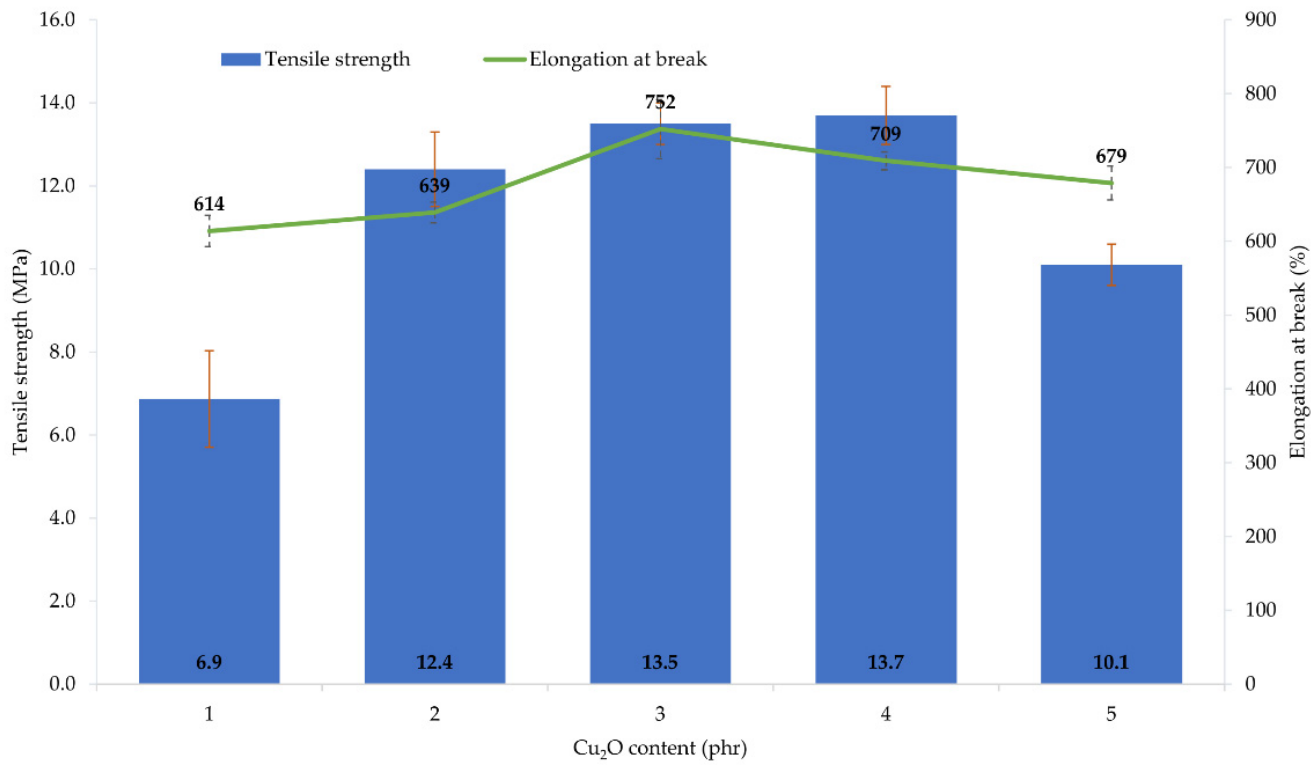

Figure 3. Mechanical properties of the $\mathrm{CR}$ compositions containing copper(I) oxide (1-5 phr of $\left.\mathrm{Cu}_{2} \mathrm{O}\right)$; $T=160^{\circ} \mathrm{C}, t=45 \mathrm{~min}$.

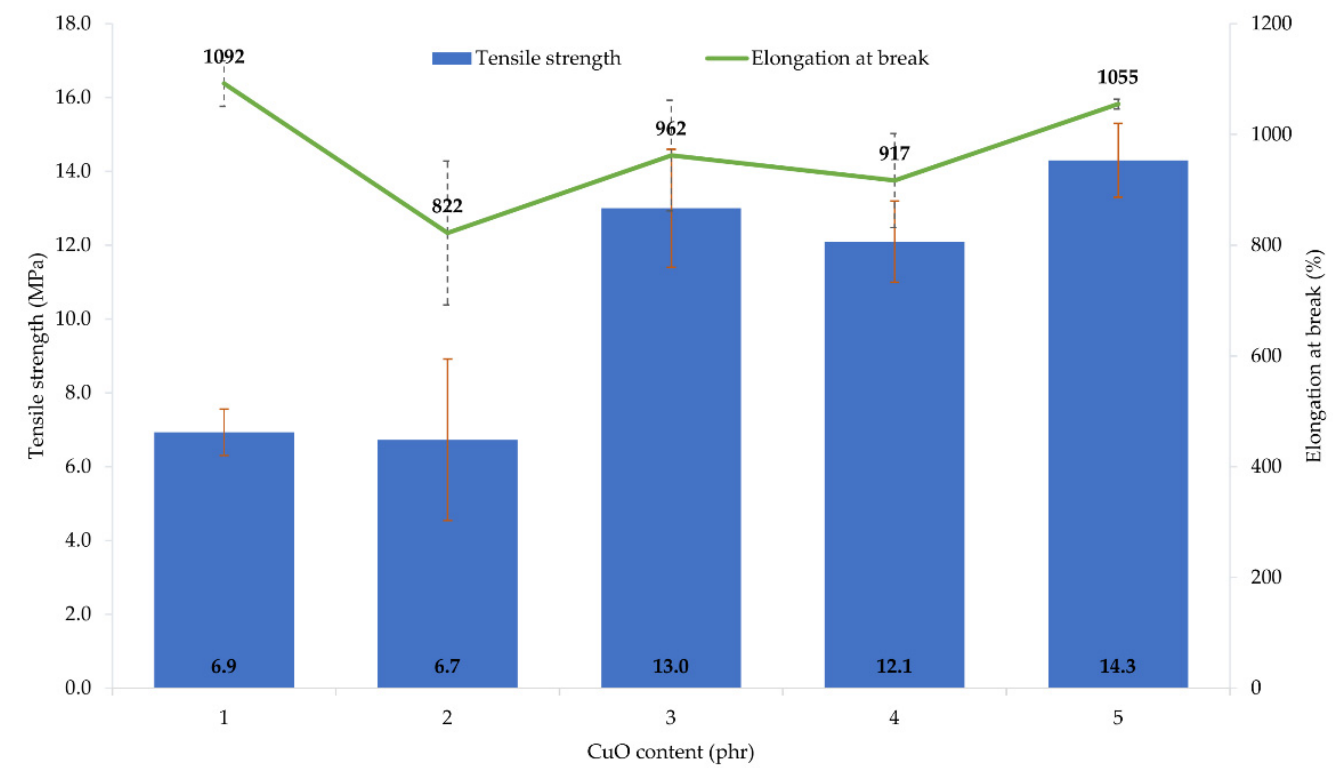

Figure 4. Mechanical properties of the CR compositions containing copper(II) oxide (1-5 phr of CuO); $T=160{ }^{\circ} \mathrm{C}, t=45 \mathrm{~min}$.

\subsection{Infrared Spectra of CR Cross-Linked with Copper Oxides}

Infrared spectra confirmed that copper oxides can cross-link the CR compositions. An increase in the intensity of the peaks at the wavenumbers of 2915 and $2847 \mathrm{~cm}^{-1}$ corresponds with the stretching of $-\mathrm{CH}_{2}$-, asymmetric and symmetric, respectively (Figures 5 and 6). The decreasing intensity of the absorption peak at the wavenumber of $1655 \mathrm{~cm}^{-1}$ ( $>\mathrm{C}=\mathrm{C}<$ stretching) may indicate the formation of bonds between elastomer macromolecules, by breaking the double bonds in the $\mathrm{CR}$ chain. Medium and strong peaks at the wavenumbers 1471 and $1428 \mathrm{~cm}^{-1}$, respectively, are attributed to $-\mathrm{CH}_{2}$ - deformations. Shifts in the intensity of these bands indicate the changes taking place in CR during its heating in the presence of copper oxides. Changing intensity of the absorption peak at the wavenumber of $1296 \mathrm{~cm}^{-1}$ corresponds with the wagging of $-\mathrm{CH}_{2}$ - In turn, the change in band intensity at wavenumber 1109 is attributed to the $C-C$ stretch of the $C R$ main chain, which can provide 
the reorganization of structures when the blends were heated in the presence of copper oxides. The decreasing intensity of the absorption peak at the wavenumber of $822 \mathrm{~cm}^{-1}$ is attributed to $-\mathrm{CH}_{2}$ - rocking corresponds with the changes in methylene groups shown in other bands. The absorption peak at the wavenumber of $727 \mathrm{~cm}^{-1}$ is attributed to in-plane bending of -C-C-bonds in CR main chain. The decreasing intensity of the absorption peak at the wavenumber of $668 \mathrm{~cm}^{-1}$ (-C-Cl stretching) clearly illustrates that, when the CR is heated in the presence of copper oxides, the elastomer cross-links.

IR spectra analysis allows the assumption that copper oxides can be a substitute for zinc oxide as cross-linking substance. Instead of the Lewis acid $\mathrm{ZnCl}_{2}$ formed during traditional $\mathrm{CR}$ cross-linking, it is likely that $\mathrm{CuCl}$ or $\mathrm{CuCl}_{2}$ is formed when a given copper oxide is used $\left(\mathrm{Cu}_{2} \mathrm{O}\right.$ and $\mathrm{CuO}$, respectively). The type of used copper oxide does not significantly change the intensity of the bands, which proves the formation of a comparable network structure.

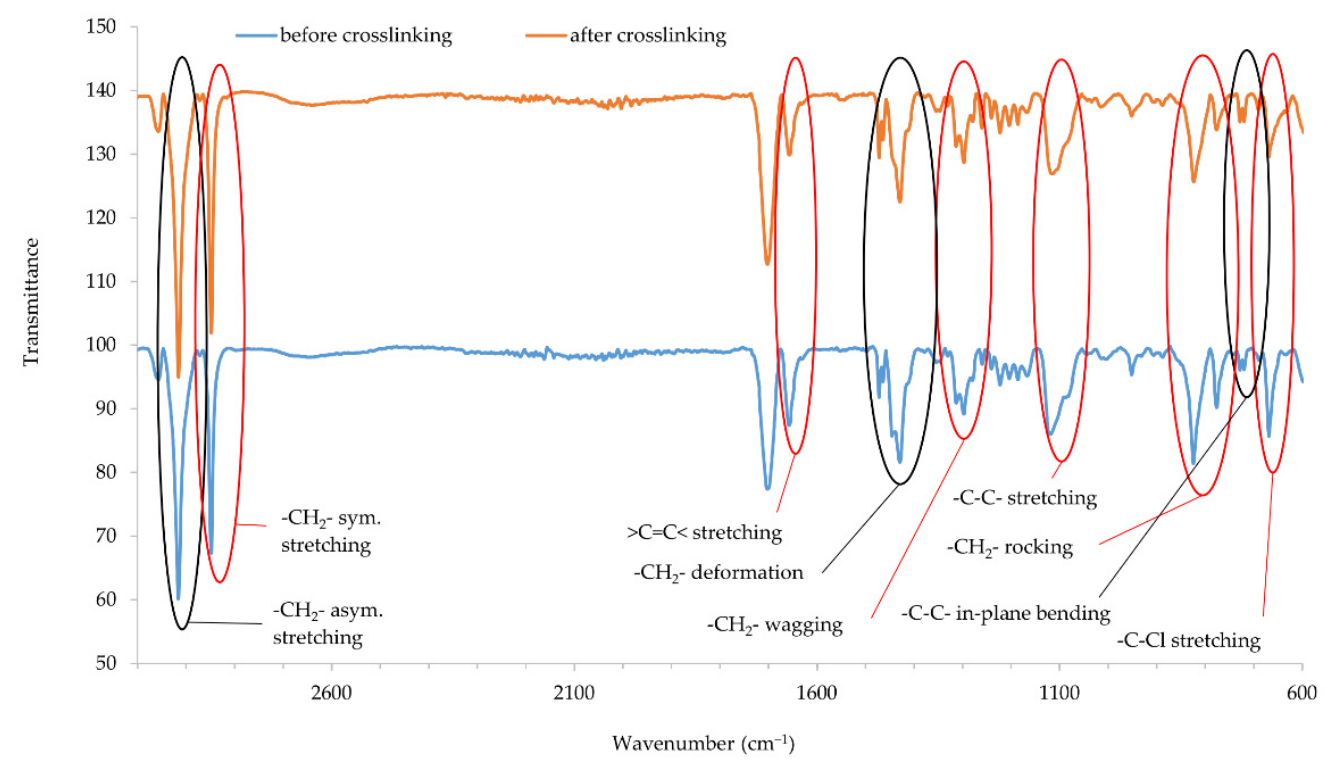

Figure 5. IR spectra of $\mathrm{CR}$ composition cross-linked with copper(I) oxide $\left(3 \mathrm{phr}\right.$ of $\left.\mathrm{Cu}_{2} \mathrm{O}\right) ; \mathrm{T}=160{ }^{\circ} \mathrm{C}$, $t=45 \mathrm{~min}$.

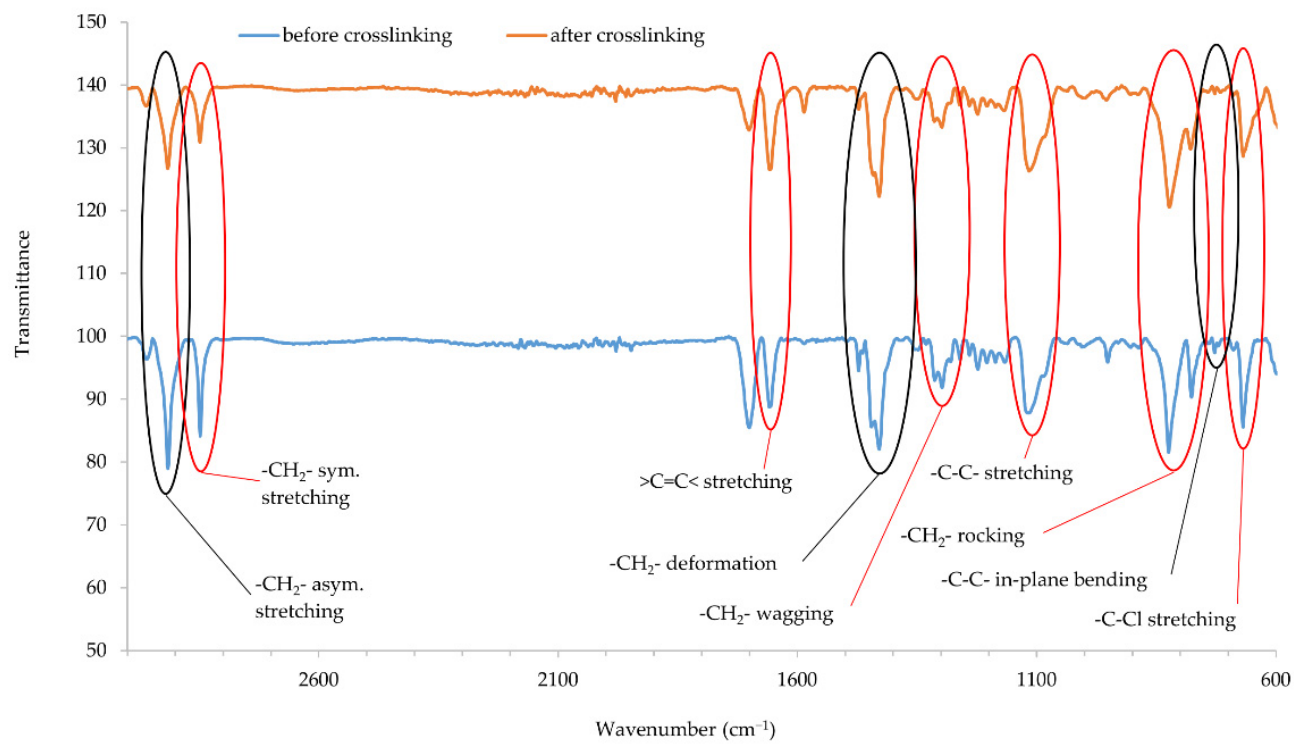

Figure 6. IR spectra of CR composition cross-linked with copper(II) oxide ( 3 phr of $\mathrm{CuO}) ; \mathrm{T}=160^{\circ} \mathrm{C}$, $t=45 \mathrm{~min}$. 


\subsection{Thermal Analysis of CR Cross-Linked with Copper Oxides}

Using the differential scanning calorimetry allowed us to determine the glass transition temperature of the compositions. For all tested samples, the glass transition temperature was approximately $-38{ }^{\circ} \mathrm{C}$ (Figure 7). For the $\mathrm{CR} / \mathrm{Cu}_{2} \mathrm{O}-3: \mathrm{T}_{\mathrm{g}}=-38.51{ }^{\circ} \mathrm{C}$, for the $\mathrm{CR} / \mathrm{Cu}_{2} \mathrm{O}-5: T_{\mathrm{g}}=-38.15^{\circ} \mathrm{C}$, for the $\mathrm{CR} / \mathrm{CuO}-3: \mathrm{T}_{\mathrm{g}}=-38.72{ }^{\circ} \mathrm{C}$, and for the $\mathrm{CR} / \mathrm{Cu}_{2} \mathrm{O}-3$ : $T_{\mathrm{g}}=-37.95^{\circ} \mathrm{C}$. Almost identical glass transition temperatures prove that the type and amount of copper oxide do not influence this parameter. For comparison, standard crosslinked $\mathrm{CR}$ has a glass transition temperature ranging from -50 to $-40{ }^{\circ} \mathrm{C}[41,42]$. This proves a slight influence of copper oxides on increasing the glass transition temperature of the $\mathrm{CR}$ composition. At the temperature of $\sim 39^{\circ} \mathrm{C}$, a significant endothermic peak appears, which proves the melting of the crystalline structures formed over time in chloroprene rubber during its storage. Up to the temperature of $\sim 10{ }^{\circ} \mathrm{C}$, the characteristics of the curves are almost identical for all tested samples. Above this temperature, the characteristics fluctuate, which indicates changes in the material depending on its composition. In the temperature range from 125 to $179^{\circ} \mathrm{C}$, an exothermic peak appears, which proves that the composition is cross-linked by copper oxides. In the case of samples containing copper(I) oxide, the exothermic peak is wider. For the $\mathrm{CR} / \mathrm{Cu}_{2} \mathrm{O}-3$, the peak is in the range of $126-179{ }^{\circ} \mathrm{C}$ with a maximum at $151{ }^{\circ} \mathrm{C}$. However, for the $\mathrm{CR} / \mathrm{Cu}_{2} \mathrm{O}-5$, the peak is in the range $135-165{ }^{\circ} \mathrm{C}$, with the maximum temperature at $151^{\circ} \mathrm{C}$. For the $\mathrm{CR} / \mathrm{CuO}-3$, the width of the exothermic peak is smaller and is in the temperature range $128-152{ }^{\circ} \mathrm{C}$ with a maximum at $141^{\circ} \mathrm{C}$. In turn, for the $\mathrm{CR} / \mathrm{CuO}-5$, two peaks can be observed-the first at a maximum of $136{ }^{\circ} \mathrm{C}$, and the second at $211^{\circ} \mathrm{C}$. From the obtained results, it can be observed that the type and amount of copper oxide affects not only the cross-linking of the composition but also causes changes in the structure of the entire material along with a further temperature increase in the system.

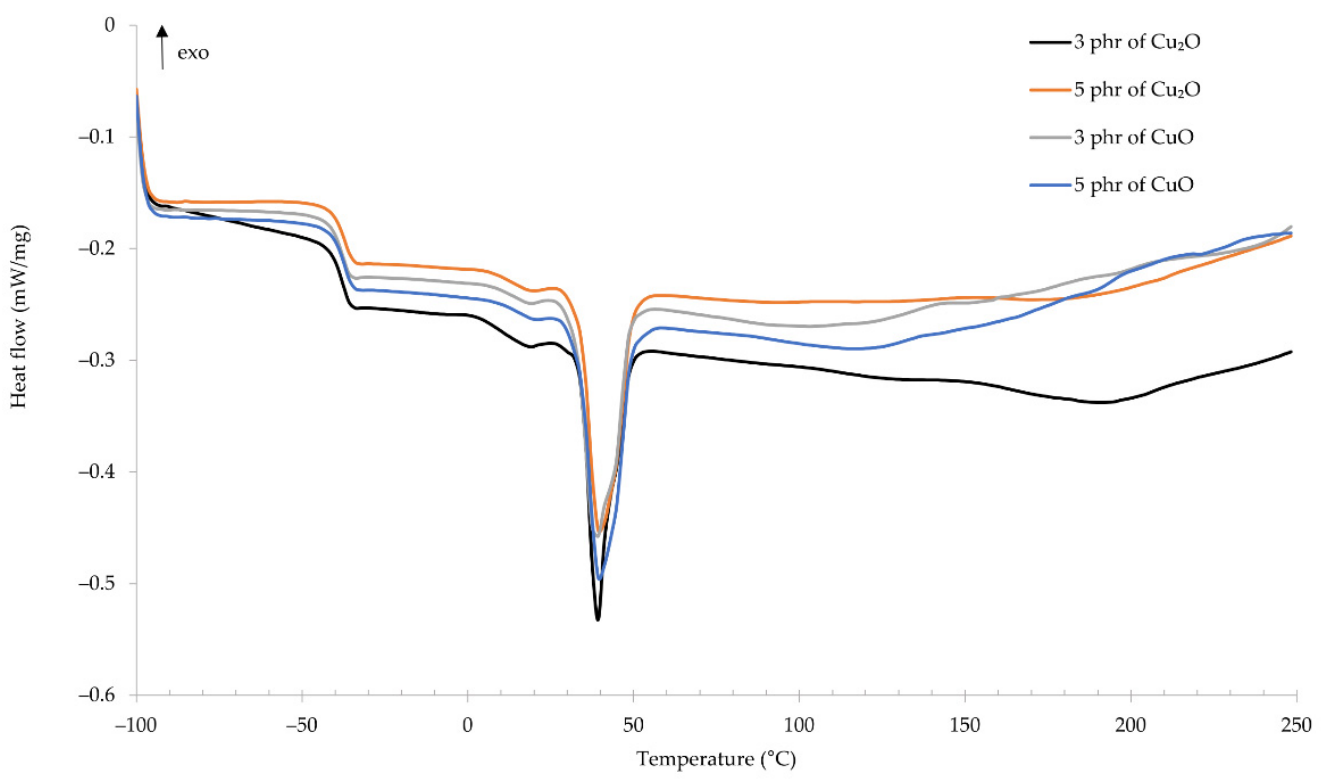

Figure 7. DSC spectrum of CR compositions; $T=160^{\circ} \mathrm{C}, t=45 \mathrm{~min}$.

Thermogravimetric curves allowed us to determine the processes occurring in vulcanizates during their heating. The first weight loss of the samples occurs at a temperature range $368-373{ }^{\circ} \mathrm{C}$, where the pyrolysis of the material begins (Figure 8 ). The weight loss of the samples was in the range of $26-29 \%$. The second stage of pyrolysis occurs at the temperature range of $463-466{ }^{\circ} \mathrm{C}$. The weight loss of the samples in this stage was also about $30 \%$. At the temperature of $\sim 660^{\circ} \mathrm{C}$, carbon black formed during pyrolysis, combusts as a result of changing gas from argon to air. The course of the thermogravimetric curves up to the temperature of $\sim 500{ }^{\circ} \mathrm{C}$ is almost identical. Above this temperature, it can be observed that the weight loss of samples containing $3 \mathrm{phr}$ of copper oxides is greater 
than that of samples containing $5 \mathrm{phr}$. This may result from the lower amount of organic components that may remain unburned at higher temperatures.

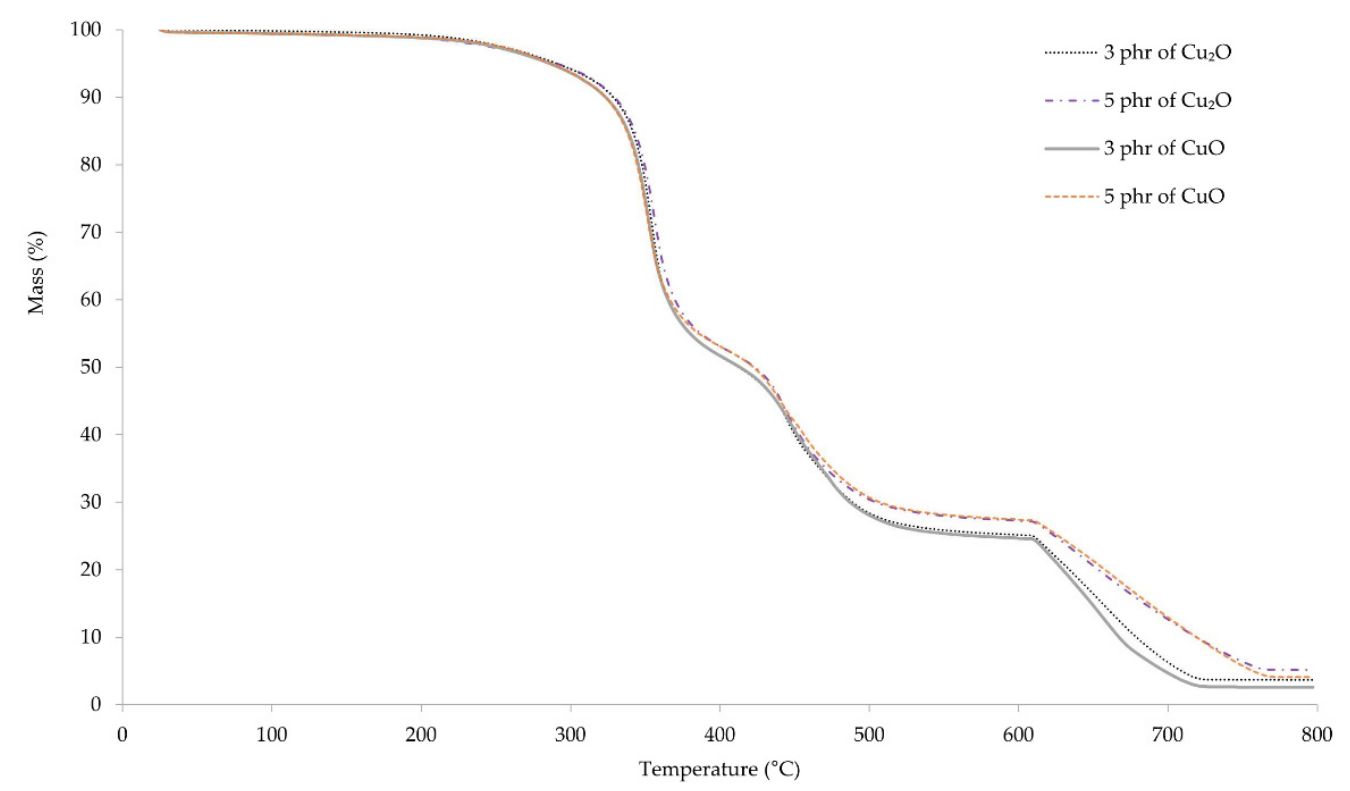

Figure 8. TGA spectrum of $\mathrm{CR}$ vulcanizates; $\mathrm{T}=160^{\circ} \mathrm{C}, t=45 \mathrm{~min}$.

\section{Conclusions}

In summary, chloroprene rubber can be cross-linked with copper oxides. The amount and type of copper oxide affect the cross-linking and properties of vulcanizates. When using copper(II) oxide, the properties are linearly dependent on the amount of $\mathrm{CuO}$. The lowest cross-linking degree and mechanical properties were obtained for the CR crosslinked with $1 \mathrm{phr}$ of $\mathrm{CuO}$. In turn, the largest is for the $\mathrm{CR}$ cross-linked with $5 \mathrm{phr}$ of $\mathrm{CuO}$. The optimal is the use of $3 \mathrm{phr}$ of $\mathrm{CuO}$ as $\mathrm{CR}$ cross-linking agent. This is evidenced by the comparable cross-linking degree and properties of vulcanizates containing $3-5 \mathrm{phr}$ of $\mathrm{CuO}$. In this case, an economic factor must also be included, which will promote the use of less amount of the cross-linking agent. When using $\mathrm{Cu}_{2} \mathrm{O}$ as a cross-linking agent, it is difficult to indicate the relationship between the amount of copper(I) oxide and the properties of vulcanizates. When analyzing individual parameters, the best results are obtained for different samples. Such lack of dependence may result from changes taking place in the substrates during the heating of the composition (e.g., oxidation of copper(I) oxide, reorganization of the network). Among the tested samples, the optimal seems to be the use of $3 \mathrm{phr}$ of $\mathrm{Cu}_{2} \mathrm{O}$ as a cross-linking agent. This is evidenced by the high values of the tensile strength and the first elasticity constant. Infrared spectroscopy studies confirm the ability of copper oxides to cross-link chloroprene rubber. This is evidenced by the characteristic changes in the intensity of the bands. The thermal analysis allowed to determine the changes occurring in the materials during their heating. Regardless of the type and amount of copper oxide, all compositions exhibit similar characteristics, and the glass transition temperature is nearly identical. The greatest changes can be seen in the DSC analysis after exceeding the temperature of $100{ }^{\circ} \mathrm{C}$, which may indicate structural changes in the material, depending on the cross-linking substance used. A list of abbreviations used in this article is provided in Table 5. 
Table 5. List of abbreviations used in the article with descriptions.

\begin{tabular}{|c|c|}
\hline Symbol & Description \\
\hline IR & infrared spectroscopy \\
\hline DSC & differential scanning calorimetry \\
\hline TGA & thermogravimetric analysis \\
\hline CR & chloroprene rubber \\
\hline CSM & chlorosulfonated polyethylene \\
\hline CIIR & chlorobutyl \\
\hline BIIR & bromobutyl \\
\hline XNBR & carboxylated acrylonitrile-butadiene rubber \\
\hline SBR & styrene-butadiene rubber \\
\hline $\mathrm{BR}$ & butadiene rubber \\
\hline $\mathrm{Cu}_{2} \mathrm{O}$ & copper(I) oxide \\
\hline $\mathrm{CuO}$ & copper(II) oxide \\
\hline $\mathrm{ZnO}$ & zinc oxide \\
\hline $\mathrm{MgO}$ & magnesium oxide \\
\hline $\mathrm{Fe}_{2} \mathrm{O}_{3}$ & iron(III) oxide \\
\hline $\mathrm{Fe}_{3} \mathrm{O}_{4}$ & iron(II,III) oxide \\
\hline $\mathrm{Al}_{2} \mathrm{O}_{3}$ & aluminum(III) oxide \\
\hline $\mathrm{CaO}$ & calcium oxide \\
\hline $\mathrm{TiO}_{2}$ & titanium(IV) oxide \\
\hline $\mathrm{ZnCl}_{2}$ & zinc chloride \\
\hline $\mathrm{CuCl}$ & copper(I) chloride \\
\hline $\mathrm{CuCl}_{2}$ & copper(II) chloride \\
\hline phr & parts per hundred rubber \\
\hline$\Delta M_{x}$ & torque increment after a given time of heating $(\mathrm{dN} \cdot \mathrm{m})$ \\
\hline$M_{x}$ & torque after a given time of heating $(\mathrm{dN} \cdot \mathrm{m})$ \\
\hline$M_{\min }$ & minimum torque $(\mathrm{dN} \cdot \mathrm{m})$ \\
\hline$t_{02}$ & scorch time $(\mathrm{min})$ \\
\hline$t_{90}$ & cure time $(\mathrm{min})$ \\
\hline$Q_{V}^{\mathrm{T}}$ & equilibrium volume swelling in toluene $\left(\mathrm{cm}^{3} / \mathrm{cm}^{3}\right)$ \\
\hline$\widetilde{Q}_{V}^{H}$ & equilibrium volume swelling in heptane $\left(\mathrm{cm}^{3} / \mathrm{cm}^{3}\right)$ \\
\hline$\widetilde{Q}_{W}$ & equilibrium weight swelling $(\mathrm{mg} / \mathrm{mg})$ \\
\hline$\widetilde{d}_{\mathrm{V}}$ & vulcanizate density $\left(\mathrm{g} / \mathrm{cm}^{3}\right)$ \\
\hline$d_{\mathrm{s}}$ & solvent density $\left(\mathrm{g} / \mathrm{cm}^{3}\right)$ \\
\hline$m_{\mathrm{s}}$ & swollen sample weight (mg) \\
\hline$m_{\mathrm{d}}$ & dry sample weight (mg) \\
\hline$m_{\mathrm{d}}^{*}$ & reduced sample weight $(\mathrm{mg})$ \\
\hline$m_{0}$ & initial sample weight $(\mathrm{mg})$ \\
\hline$m_{\mathrm{m}}$ & mineral content in the blend (mg) \\
\hline$m_{\mathrm{t}}$ & total weight of the blend (mg) \\
\hline$m$ & final sample weight $(\mathrm{mg})$ \\
\hline$C_{1}$ & first elasticity constant $\left(\mathrm{kG} / \mathrm{cm}^{2}\right)$ \\
\hline$C_{2}$ & second elasticity constant $\left(\mathrm{kG} / \mathrm{cm}^{2}\right)$ \\
\hline$P$ & deformation force at $\lambda(\mathrm{kG})$ \\
\hline$\lambda$ & deformation $\left(\lambda=1 / 1_{0}\right)$ \\
\hline$l$ & measuring section of the sample loaded with $\mathrm{P}(\mathrm{cm})$ \\
\hline$l_{0}$ & measuring section of the unloaded sample $(\mathrm{cm})$ \\
\hline$A_{0}$ & cross-sectional area of the unloaded sample $\left(\mathrm{cm}^{2}\right)$ \\
\hline$E_{\mathrm{R}}$ & real extract in acetone $(\mathrm{mg} / \mathrm{mg})$ \\
\hline$S_{\mathrm{e} 100}$ & stress at elongation $100 \%(\mathrm{MPa})$ \\
\hline$S_{\mathrm{e} 200}$ & stress at elongation $200 \%(\mathrm{MPa})$ \\
\hline$S_{\mathrm{e} 300}$ & stress at elongation $300 \%(\mathrm{MPa})$ \\
\hline$T S_{\mathrm{b}}$ & tensile strength (MPa) \\
\hline$E_{\mathrm{b}}$ & elongation at break (\%) \\
\hline$T_{\mathrm{g}}$ & glass transition temperature \\
\hline
\end{tabular}


Author Contributions: Conceptualization, P.K. and A.S.-K.; methodology, P.K. and A.S.-K.; validation, K.S.; formal analysis, P.K. and A.S.-K.; investigation, P.K.; resources, P.K. and A.S.-K.; data curation, P.K. and A.S.-K.; writing-original draft preparation, P.K.; writing-review and editing, P.K. and A.S.-K.; visualization, P.K.; supervision, K.S. All authors have read and agreed to the published version of the manuscript.

Funding: This research received no external funding.

Institutional Review Board Statement: Not applicable.

Informed Consent Statement: Not applicable.

Data Availability Statement: Data sharing not applicable.

Conflicts of Interest: The authors declare no conflict of interest.

\section{References}

1. De, S.K.; White, J.R. Rubber Technologist's Handbook, 1st ed.; Rapra Technology Limited: Shrewbury, UK, 2001 ; pp. 39-203.

2. Sarkar, S.; Guibal, E.; Quignard, F.; SenGupta, A. Polymer-supported metals and metal oxide nanoparticles: Synthesis, characterization, and applications. J. Nanopart. Res. 2012, 14, 715. [CrossRef]

3. Fishbein, L. Chemicals Used in the Rubber Industry. In Anthropogenic Compounds (The Handbook of Environmental Chemistry), 1st ed.; Hutzinger, O., Ed.; Springer: Berlin/Heidelberg, Germany, 1990; pp. 45-95.

4. Li, J.; Isayev, A.I.; Ren, X.; Soucek, M.D. Effect of norbornyl modified soybean oil on CR-filled chloroprene rubber. J. Appl. Polym. Sci. 2016, 133, 43809. [CrossRef]

5. Topham, P.D.; Berry, K.; Liu, M.; Chakraborty, K.; Pullan, N.; West, A.; Sammon, C. Mechanism for crosslinking polychloroprene with ethylene thiourea and zinc oxide. Rubber Chem. Technol. 2015, 88, 80-97.

6. Pöschl, M.; Gopi Sathi, S.; Stoček, R.; Kratina, O. Rheometer Evidences for the Co-Curing Effect of a Bismaleimide in Conjunction with the Accelerated Sulfur on Natural Rubber/Chloroprene Rubber Blends. Polymers 2021, 13, 1510. [CrossRef] [PubMed]

7. Xu, Z.; Zheng, L.; Wen, S.; Liu, L. Graphene oxide-supported zinc oxide nanoparticles for chloroprene rubber with improved crosslinking network and mechanical properties. Compos. A Appl. Sci. Manuf. 2019, 124, 105492. [CrossRef]

8. Smejda-Krzewicka, A.; Słubik, A.; Strzelec, K.; Rybiński, P. Study on the Effect of Zinc on the Rheological, Mechanical and Thermal Properties and Fire Hazard of Unfilled and Filled CR/BR Vulcanizates. Polymers 2020, 12, 2904. [CrossRef]

9. Owczarek, M.; Zaborski, M. Chlorosulfonated polyethylene elastomers containing zinc oxide incorporated on $\mathrm{SiO}_{2}$. KGK-Kaut. Gummi. Kunst. 2004, 57, 218-223.

10. Hendrikse, K.; McGill, W. Vulcanization of chlorobutyl rubber. II. A revised cationic mechanism of $\mathrm{ZnO} / \mathrm{ZnCl} 2$ initiated crosslinking. J. Appl. Polym. Sci. 2000, 78, 2302-2310. [CrossRef]

11. He, X.; Yu, H.; Wang, X.; Rong, Y.; Zhang, R. The Influence of Vulcanization Agents on Vulcanization Kinetics of Chloride Butyl Rubber. Int. Polym. Process. 2013, 28, 398-414. [CrossRef]

12. Vukow, R. Zinc Oxide Crosslinking Chemistry of Halobutyl Elastomers-A Model Compound Approach. Rubber Chem. Technol. 1984, 57, 284-290.

13. Dziemidkiewicz, A.; Maciejewska, M.; Pingot, M. Thermal analysis of halogenated rubber cured with a new cross-linking system. J. Therm. Anal. Calorim. 2019, 138, 4395-4405. [CrossRef]

14. Chokanandsombat, Y.; Sirisinhal, C. MgO and ZnO as Reinforcing Fillers in Cured Polychloroprene Rubber. J. Appl. Polym. Sci. 2013, 128, 2533-2540. [CrossRef]

15. Desai, H.; Hendrikse, K.G.; Woolard, C.D. Vulcanization of polychloroprene rubber. I. A revised cationic mechanism for ZnO crosslinking. J. Appl. Polym. Sci. 2007, 105, 865-876. [CrossRef]

16. Smejda-Krzewicka, A.; Rzymski, W.M. Crosslinking of new elastomers functionalized with carboxyl groups. Polimery 2006, 51, 66-68. [CrossRef]

17. Krzemińska, S.M.; Smejda-Krzewicka, A.A.; Leniart, A.; Lipińska, L.; Woluntarski, M. Effects of curing agents and modified graphene oxide on the properties of XNBR composites. Polym. Test. 2020, 83, 106368. [CrossRef]

18. Ibarra, L.; Alzorriz, M. Ionic Elastomers Based on Carboxylated Nitrile Rubberand Magnesium Oxide. J. Appl. Polym. Sci. 2006, 103, 1894-1899. [CrossRef]

19. Mesuda, I.; Ota, K.; Tateishi, Y.; Hayano, S. Anti-Static Agent, and Composition for Molding and Crosslinkable Composition in which Same Is Used. U.S. Patent No. US 2020/0040241, 6 February 2020.

20. Smejda-Krzewicka, A.; Olejnik, A.; Strzelec, K. The role of iron(III) oxide in chloroprene and butadiene rubber blends' crosslinking, structure, thermal and mechanical characteristics. Iran. Polym. J. 2019, 28, 313-323. [CrossRef]

21. Smejda-Krzewicka, A.; Olejnik, A.; Strzelec, K. The effect of metal oxide on the cure, morphology, thermal and mechanical characteristics of chloroprene and butadiene rubber blends. Polym. Bull. 2020, 77, 4131-4146. [CrossRef]

22. Olejnik, A.; Smejda-Krzewicka, A.; Strzelec, K.; Szynkowska, M.I. Curing and properties of chloroprene and butadiene rubber (CR/BR) blends cross-linked with copper(I) oxide or copper(II) oxide. Int. J. Polym. Anal. Charact. 2019, 24, 18-31. [CrossRef] 
23. Olejnik, A.; Smejda-Krzewicka, A.; Strzelec, K. Effect of antioxidants on aging of the chloroprene rubber/butadiene rubber (CR/BR) blends. Int. J. Polym. Anal. Charact. 2019, 24, 475-486. [CrossRef]

24. Kobędza, P.; Smejda-Krzewicka, A.; Olejnik, A.; Strzelec, K. Flame retardant and durable chloroprene rubber and styrenebutadiene rubber blends crosslinked with copper(I) oxide. Iran. Polym. J. 2021, 30, 149-165. [CrossRef]

25. Smejda-Krzewicka, A.; Kobędza, P.; Olejnik, A.; Strzelec, K. Method for Obtaining Elastomere Compositions That Contain Styrene-Butadiene Rubber with Increased Burning Resistance. Polish Patent No. PL 231634, 29 March 2019.

26. Olejnik, A.; Smejda-Krzewicka, A.; Kobędza, P.; Strzelec, K.; Dzbik, M. Method for Crosslinking and Modification of Butadiene Rubber. Polish Patent No. PL 234167, 31 January 2020.

27. Smejda-Krzewicka, A.; Olejnik, A.; Strzelec, K.; Kobędza, P. Method for Crosslinking and Modification of Chloroprene Rubber with Butadiene-Styrene Rubber Mixes. Polish Patent No. PL 234660, 31 March 2020.

28. Sheikh, S.H.; Yin, X.; Ansarifar, A.; Yendall, K. The potential of kaolin as a reinforcing filler for rubber composites with new sulfur cure systems. J. Reinf. Plast. Compos. 2017, 36, 1132-1145. [CrossRef]

29. Feriancová, A.; Pajtášová, M.; Paliesková, J.; Ondrušová, D.; Kopcová, M.; Jóna, E.; Mojumdar, S.C. The influence of kaolin filler on thermal and spectral characteristics of rubberizing components without rubber. J. Therm. Anal. Calorim. 2013, 112, 1047-1052. [CrossRef]

30. Tawfik, M.; Ahmed, N.; Ward, A. Characterization of Kaolin-Filled Polymer Composites. 2018. Available online: https://www. researchgate.net/publication/326405402_Characterization_of_kaolin-filled_polymer_composites (accessed on 14 September 2021). [CrossRef]

31. Wu, W.; Tian, L. Formulation and morphology of kaolin-filled rubber composites. Appl. Clay Sci. 2013, 80-81, 93-97. [CrossRef]

32. Visser, S.A. Effect of filler type on the response of polysiloxane elastomers to cyclic stress at elevated temperatures. J. Appl. Polym. Sci. 1997, 63, 1805-1820. [CrossRef]

33. Heideman, G.; Noordermeer, J.; Datta, R.; Baarle, B.V. Effect of metal oxides as activator for sulphur vulcanisation in various rubbers. KGK-Kaut. Gummi. Kunst. 2005, 58, 30-42.

34. Datta, J.; Kosiorek, P.; Włoch, M. Effect of high loading of titanium dioxide particles on the morphology, mechanical and thermo-mechanical properties of the natural rubber-based composites. Iran. Polym. J. 2016, 25, 1021-1035. [CrossRef]

35. Gázquez, M.; Bolívar, J.; Garcia-Tenorio, R.; Vaca, F. A Review of the Production Cycle of Titanium Dioxide Pigment. Mater. Sci. Appl. 2014, 5, 441-458. [CrossRef]

36. Ahmed, N.M.; ElNashar, D.E. The effect of zinc oxide-phosphate core-shell pigments on the properties of blend rubber composites. Mater. Des. 2013, 44, 1-11. [CrossRef]

37. Standard Test Method for Rubber Property_Vulcanization Using Rotorless Cure Meters; American Society for Testing and Materials: West Conshohocken, PA, USA, 2019.

38. Mooney, M. A Theory of Large Elastic Deformation. J. Appl. Phys. 1940, 11, 582-592. [CrossRef]

39. Rivlin, R.S. Large elastic deformations of isotropic materials. I. Fundamental concepts. Philos. Trans. R. Soc. A 1948, 240, 459-490.

40. Guma i Kauczuk Termoplastyczny—OZNACZANIE Właściwości Wytrzymałościowych Przy Rozciaganiu; Polski Komitet Normalizacyjny: Warsaw, Poland, 2007. Available online: https://sklep.pkn.pl/pn-iso-37-2007p.html (accessed on 14 September 2021).

41. Kell, R.M.; Bennett, B.; Stickney, P.B. Transition behavior of polychloroprene and polychloroprene/styrene-butadiene blends. J. Appl. Polym. Sci. 1959, 2, 8-13. [CrossRef]

42. Maeda, S.; Yoshida, J.; Ura, Y.; Haraguchi, H.; Sugawara, J. Air Springs for Railways Available for Very Cold Environments. SEI Tech. Rev. 2015, 51, 63-66. 